\title{
Eutrophication control in river-systems: an application of INCA-P to the River Lugg
}

\author{
A.J. Wade ${ }^{1}$, D. Butterfield ${ }^{1}$, T. Griffiths ${ }^{2}$ and P.G. Whitehead ${ }^{1}$ \\ ${ }^{1}$ Aquatic Environments Research Centre, School of Human and Environmental Sciences, The University of Reading, Reading, RG6 6AB, UK \\ ${ }^{2}$ Environment Agency, Rivers House, Fortran Road, St. Mellons, Cardiff, CF3 0EY, UK
}

Email for corresponding author: a.j.wade@reading.ac.uk

\begin{abstract}
The Integrated Catchments model of Phosphorus dynamics (INCA-P) was applied to the River Lugg to determine the key factors controlling delivery of phosphorus to the main channel and to quantify the relative contribution of diffuse and point sources to the in-stream phosphorus (P) load under varying hydrological conditions. The model is able to simulate the seasonal variations and inter-annual variations in the in-stream total-phosphorus concentrations. However, difficulties in simulating diffuse inputs arise due to equifinality in the model structure and parameters. The River Lugg is split into upper and lower reaches. The upper reaches are dominated by grassland and woodland, so the patterns in the stream-water total-phosphorus concentrations are typical of diffuse source inputs; application of the model leads to estimates of the relative contribution to the in-stream P load from diffuse and point sources as 9:1. In the lower reaches, which are more intensively cultivated and urbanised, the stream-water total-phosphorus concentration dynamics are influenced more by point-sources; the simulated relative diffuse/point contribution to the in-stream P load is 1:1. The model set-up and simulations are used to identify the key source-areas of $\mathrm{P}$ in the catchment, the $\mathrm{P}$ contribution of the Lugg to the River Wye during years with contrasting precipitation inputs, and the uptake and release of P from within-reach sediment. In addition, model scenarios are run to identify the impacts of likely P reductions at sewage treatment works on the in-stream soluble-reactive P concentrations and the suitability of this as a management option is assessed for reducing eutrophication.
\end{abstract}

Keywords: water quality; model; INCA-P; nutrient, phosphorus; catchment, Lugg; Wye

\section{Introduction}

Increased phosphorus (P) loads to lakes and river systems can affect the composition and diversity of aquatic plant species, attached algae and phytoplankton by changing the competitive balance (Mainstone, 2000). As part of European Union legislation that includes the Water Framework, Habitats and Urban Waste Water Treatment Directives, it is necessary to regulate the $\mathrm{P}$ loads entering lake and river systems considered sensitive to nutrient inputs (Council of the European Union, 2000). However, control measures introduced in response to Directives and environmental policies, such as those incorporated in Asset Management Plans (AMPs), must balance the need between protecting the water resource, the maintenance of a viable local and national economy and the provision of drinking water and disposal of effluent.

Mathematical models can aid the understanding of $\mathrm{P}$ dynamics within river systems. Such models link contemporary ideas of $\mathrm{P}$ transport and storage thereby aiding the understanding of the hydrochemical and ecological functioning. Moreover, models provide initial quantification of the potential impacts of changing $\mathrm{P}$ loads on the water quality and ecology of aquatic environments. Such quantification is especially important when assessing the consequences of introducing potential control measures derived from current legislation.

This paper reports the results of the Integrated Catchments Model of Phosphorus dynamics (INCA-P: Wade et al., 2002a; Wade et al., 2004) to a large, regionally important water resource. INCA-P is a model that simulates total $\mathrm{P}$ concentrations and fluxes in the soils and groundwater, and also the total $\mathrm{P}$ and Soluble-Reactive $\mathrm{P}$ concentrations (SRP - essentially a measure of P) and fluxes in the stream. The model also takes things further by simulating the growth of 
macrophytes and epiphytes. INCA-P has been applied to two other river-systems in the UK: the Kennet and the Ant (Wade et al., 2004). The model application provides a quantitative assessment of (i) the location of P-rich source areas, (ii) the relative contribution to the in-stream P-load from external diffuse and point sources, and internal sources, (iii) the in-stream P-load under different hydrological conditions, and (iv) the likely impacts on the in-stream Soluble-Reactive $\mathrm{P}$ concentrations of installing tertiary $\mathrm{P}$ treatment at major sewage treatment works (STWs) discharging to the main river-channel of the Lugg.

\section{Study area, monitoring and water quality functioning}

The River Lugg flows in a south-easterly direction from Powys to join the River Wye in Herefordshire (Fig. 1a). The contributing area at Lugwardine Bridge, the lowest of the three gauging stations on the Lugg is $885 \mathrm{~km}^{2}$ (Fig. 1b)

(a)

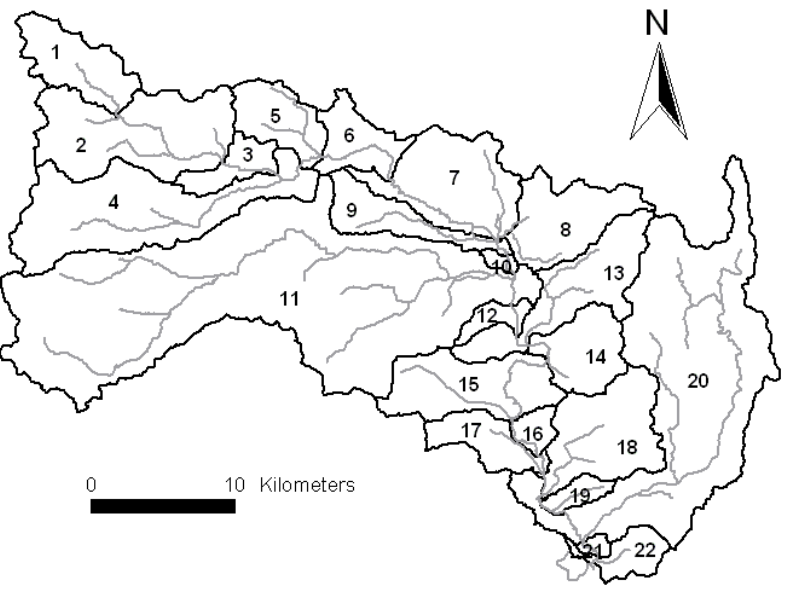

(b)

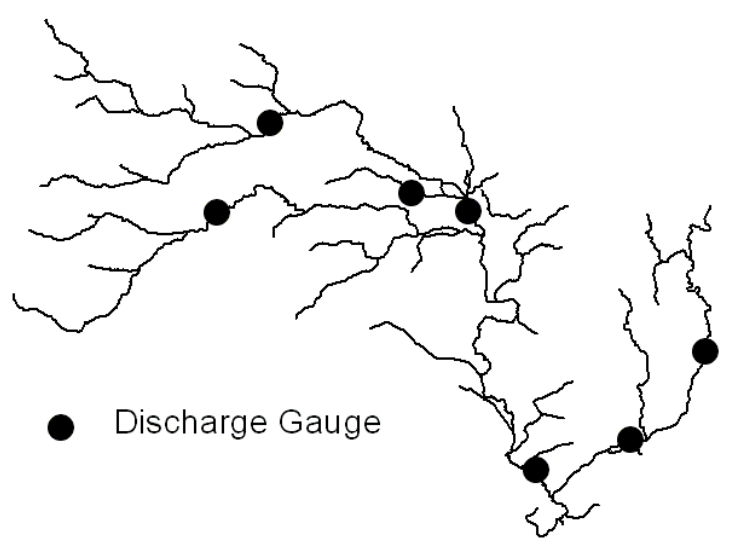

Fig. 1. (a) The reach network used to in the application of INCA-P to the River Lugg and (b) the location of the discharge gauging stations. and the total catchment area is $1077 \mathrm{~km}^{2}$.

The River Lugg was chosen as a study area because, in its lower reaches, it has very high (approximately $1 \mathrm{mg} \mathrm{P}^{-1}$ ) stream-water $\mathrm{P}$ concentrations (measured as total $\mathrm{P}, \mathrm{TP}$ ). Such is the concern about its water quality that, in 1994, the Lugg was designated a 'eutrophic sensitive' area under the Urban Wastewater Treatment Directive. Moreover, the lower Wye, into which the Lugg drains, is an Area of Outstanding Natural Beauty and considered to be of high ecological value, being a historically important Atlantic salmon (Salmo Salar) fishery.

Data describing the discharge and water quality from 1993 to 2000 were available from Environment Agency archives. These and other records were collated to provide the hydrology, land-use and land-management data needed for the application of INCA-P are listed in Table 1. The land use and livestock numbers were derived from the ADAS MAGPIE database (Lord and Anthony, 2000); this dataset is based on the Department of Environment, Food and Rural Affairs (DEFRA) agricultural census for 1995 which ADAS remapped by land use to account for undisclosed data.

The land use comprises mixed arable and cattle production. Grassland and woodland dominate in the upper regions, with woodland also scattered along the headwater and middle reaches of the main channel; arable cultivation becomes the prevailing land use in the lower part of the Lugg. Livestock production is dominated by sheep in the headwaters and by cattle in the middle and lower part of the catchment. There are notable clusters of pig production units in the River Arrow sub-catchment and to the south of Leominster, and a notable cluster of poultry units in the Hindwell Brook tributary.

Precipitation within the catchment is highly spatiallyvariable: in the upper (to Butts Bridge) and lower (to Lugwardine Bridge) reaches, the long-term annual mean rainfall is 1048 and $850 \mathrm{~mm}$, respectively. This rainfall generates approximately $394 \mathrm{~mm}$ of runoff, equivalent to a mean flow of $11.1 \mathrm{~m}^{3} \mathrm{~s}^{-1}$ at Lugwardine Bridge (Marsh and Lees, 2003). The Lugg is predominately underlain by Old Red Sandstone, although the headwaters drain Silurian rocks of the Radnor Forest. The Base Flow Index for the whole catchment is 0.66 : this value reflects this mixture of impervious rocks in the headwaters, and the sandstone aquifer and extensive deposits of gravel in the valleys, which provide significant base flow and moderate flood peaks (Marsh and Lees, 2003). The 10 percentile flow of $26 \mathrm{~m}^{3} \mathrm{~s}^{-1}$ indicates the Lugg is likely to have a high capacity to transport $\mathrm{P}$ attached to sediment during storm events.

To represent the spatial variability in the hydrological inputs of the Lugg system, two time-series were used in the model application: single-site Meteorological Office 
Table 1. Data collated for the application of INCA-P to the River Lugg.

\begin{tabular}{|c|c|c|c|c|c|}
\hline & Resolution & $\begin{array}{l}\text { Period of } \\
\text { data collection }\end{array}$ & $\begin{array}{l}\text { Storage/retrieval } \\
\text { method }\end{array}$ & Source & Reference \\
\hline \multicolumn{6}{|l|}{ Spatial data } \\
\hline Land use and livestock numbers & $1 \mathrm{~km}^{2}$ & 1995 & ESRI ArcInfo GIS & ADAS & Lord and Anthony, 2000 \\
\hline Fertiliser practice & Geoclimatic region & & Microsoft Excel & AERC & Johnes and Butterfield, 2003 \\
\hline River networks & $1: 50,000$ & & ESRI ArcInfo GIS & $\mathrm{CEH}$ & Moore et al., 1994 \\
\hline Reach boundaries & $50 \mathrm{~m}$ & & ESRI ArcInfo GIS & $\mathrm{CEH}$ & \\
\hline \multicolumn{6}{|l|}{ TEMPORAL DATA } \\
\hline $\begin{array}{l}\mathrm{TP}, \mathrm{OP}, \mathrm{SS} \text { stream } \\
\text { water concentrations }\end{array}$ & $\begin{array}{l}\text { Variable, } \\
\text { typically monthly }\end{array}$ & $\begin{array}{l}1992 \text { to present } \\
\text { day }\end{array}$ & Microsoft Access & EA & \\
\hline $\begin{array}{l}\text { *MORECS rainfall, temperature } \\
\text { and soil moisture }\end{array}$ & Daily & & Microsoft Excel & Met Office & e Hough et al., 1997 \\
\hline Growing season & $\begin{array}{l}\text { Lumped mean per } \\
\text { MORECS square }\end{array}$ & & Report & Met Office & e Hough et al., 1997 \\
\hline Discharge & Daily & & Microsoft Excel & EA & \\
\hline Base Flow Index & Each flow gauge & & Report & $\mathrm{CEH}$ & Gustard et al., 1987 \\
\hline
\end{tabular}

Rainfall and Evaporation Calculation System data (MORECS; Hough et al., 1997) for weather stations at Llandrindod Wells (in the Ithon catchment, outside the Lugg catchment) and at Madley, representing the upper and lower reaches, respectively. The MORECS data include daily estimates of precipitation, Hydrological Effective Rainfall (HER), Soil Moisture Deficit (SMD) and air temperature.

The nutrient water quality of the River Wye and River Lugg has been assessed in detail by Jarvie et al. (2003) using the Environment Agency (EA) data archive. The EA measures TP and total reactive $P$ (TRP) in the Lugg catchment. Both TP and TRP are measured using unfiltered samples. The TP is determined using the standard acidpersulphate digestion. The TRP measurement uses the colorimetric-phosphomolybdenum-blue method. Soluble reactive $\mathrm{P}(\mathrm{SRP})$ has not been measured by the Environment Agency.

There are 57 routine monitoring points within the Lugg catchment, of which eight are on the main stem. In addition, there are approximately 50 recognised inputs of STW effluent to the River Lugg and its tributaries, and a further 37 and 33 private and trade effluents, respectively (Fig. 2; the private and trade effluents are not shown). Total $\mathrm{P}$ and TRP are measured by the Environment Agency, in the samples of final effluent using the same methods as for the river samples.

The lack of SRP measurements means that INCA-P can be calibrated using TP data only. Once water chemistry data (a)

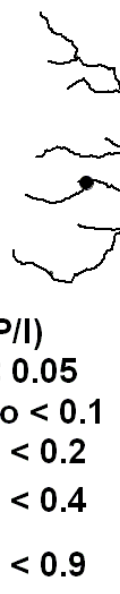

(b)

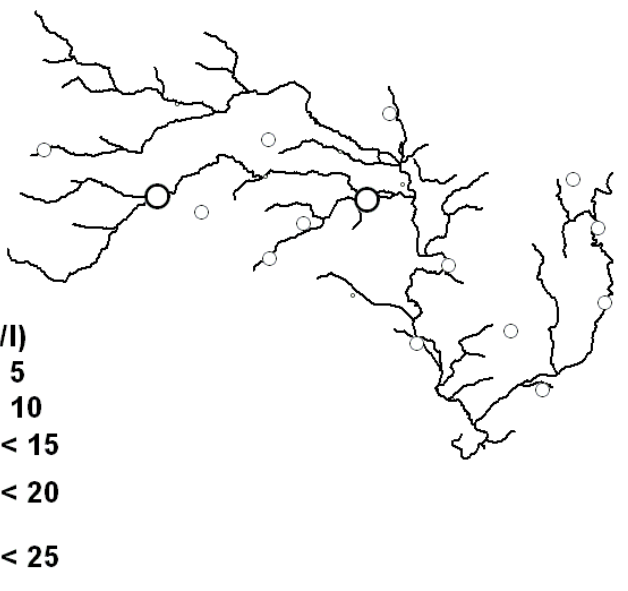

Fig. 2. Mean (a) stream water and (b) STW effluent Total P concentrations (mg $\left.P^{-1}\right)$ in the Lugg catchment over the period 2000 to 2003. 
are available publicly from the Phosphorus and Sediment Yield Characterisation project (PSYCHIC: www.psychicproject.org.uk) then these data can be used to compare with the EA TP and TRP measurements both in the Lugg and in the larger Wye catchment, and the SRP data can be used to calibrate the simulated SRP concentrations. In this study, the TRP concentrations are used as an upper bound to the simulated SRP concentrations, and the ratio between observed SRP and TP concentrations in the River Kennet are used as an approximation to guide the calibration of the INCA-P in this study. Clearly, it is desirable to have SRP and TP values since in combination these give an estimate of the particulate and solute load. The lack of SRP data limits this study to a consideration of TP mainly. This is still useful as it provides an assessment of $\mathrm{P}$ contamination in the system, though work remains on modelling the fraction of this total P load that is available biologically.

\section{UPLAND-LOWLAND CONTRAST}

The headwaters and reaches of the Lugg downstream of the confluence with the River Arrow have contrasting observed mean stream water TP concentrations (Fig. 2a). In the headwaters of the Lugg and the Arrow, the mean concentrations are typically around $0.05 \mathrm{mg} \mathrm{P}^{-1}$; the highest mean concentrations, of approximately $0.4-0.9 \mathrm{mg} \mathrm{P}^{-1}$ are found in the lower reaches of the Lugg, and in the River Frome and Stretford Brook tributaries. Comparison with land-use maps and the location and density of point source inputs indicates that the higher stream water TP concentrations correspond to the more intensive agricultural practices and the higher loadings from point sources found in the lower reaches and tributaries (Neal and Jarvie, 2005; Fig. 2b). Many of the smaller, often private, STWs can have very high TP concentrations in the effluent, reaching up to $30 \mathrm{~m} \mathrm{P}^{-1}$ in the most extreme case, although low flows from these works means the overall contribution in terms of load is small. The largest STWs within the catchment are Leominster, Weobley, Kington, Moreton and Bromyard, which were designed to serve population equivalents of 10854, 2935, 2681, 2721 and 4500 respectively. The main trade effluents are from food processing at Cadburys and Symonds Cider. P stripping was introduced at Leominster STW and Cadburys in 1998.

The contrast between the headwaters and the lower area of the Lugg catchment is apparent in the in-stream $\mathrm{P}$ dynamics (Fig. 3). At Monaughty in the upper reaches, the stream water TP concentrations show a complex relationship with flow, and it is possible to discern two clusters of points (Fig. 3a). One cluster is associated with increasing TP concentrations as flow increases from 0 to $30 \mathrm{~m}^{3} \mathrm{~s}^{-1}$ and the
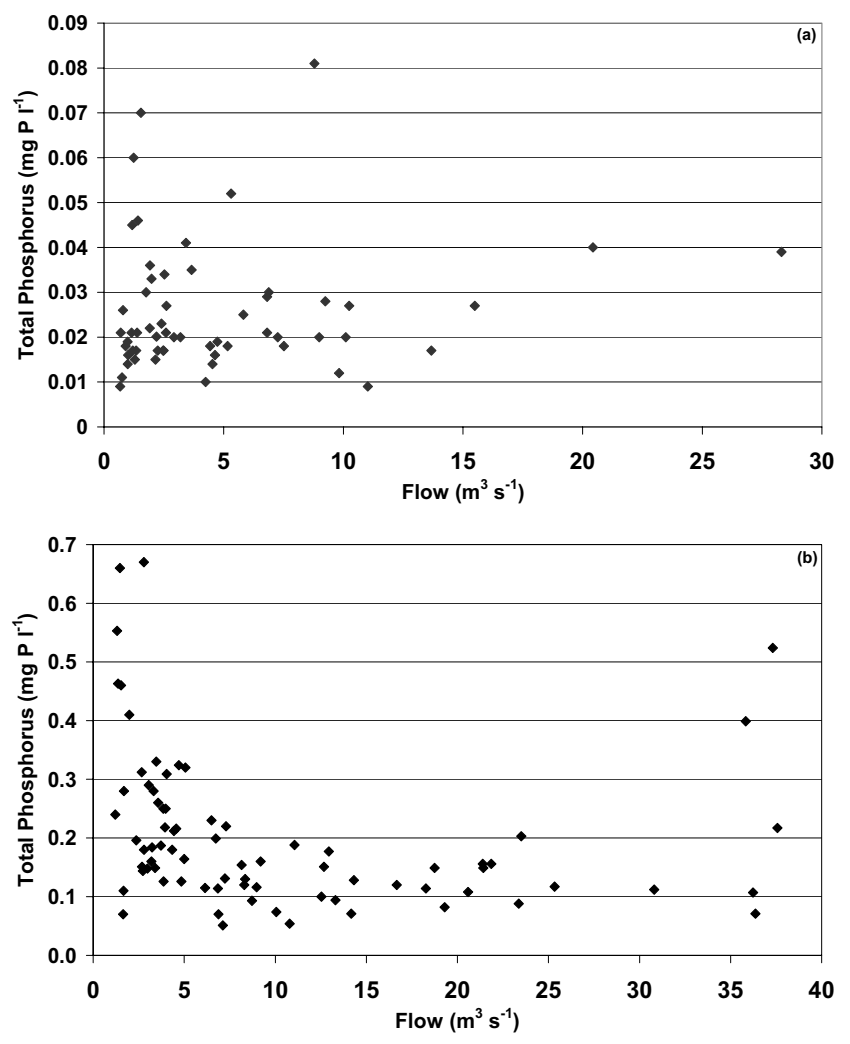

Fig. 3. Contrasting dynamics exhibited in the observed streamwater chemistry total-phosphorus concentrations at (a) an upland (Monaughty) and (b) a lowland (Mordiford Bridge) site.

other with the dilution of a point source, Llangunllo STW, at flows between 0 and $10 \mathrm{~m}^{3} \mathrm{~s}^{-1}$. The increase in TP concentration with flow is typical of a diffuse source contribution, though the response is complicated by the complex interaction between source-areas and flowpathways within the contributing catchment area.

At Mordiford Bridge, the stream water TP concentrations are an order of magnitude higher than those observed at Monaughty (Fig. 3b). The concentration-flow relationship again suggests the influence of both point and diffuse sources; at low flows $\left(0-20 \mathrm{~m}^{3} \mathrm{~s}^{-1}\right)$, TP decreases with increasing flow and, at higher flows, TP increases with increasing flow. This has been observed previously for sites on the Pang, Lambourn and Kennet (Jarvie et al., 2002; Neal et al., 2004). The decrease in TP at lower flows is indicative of dilution of point-sources. The increase in TP concentration with flow may indicate a greater contribution of P-enriched water from the soil during storm-events, or P contamination of the unsaturated zone near to the stream which is flushed to the stream when water tables rise. Such contamination may be due to septic tanks or discharges of effluent to groundwater. These P sources and pathways are 
consistent with the conceptual model produced to describe water and nutrient retention and movement in the Pang and Lambourn catchments by Neal et al. (2004).

\section{INCA-P}

The Integrated Catchments Model of Phosphorus dynamics (INCA-P) provides a process-based representation of the factors and processes controlling P dynamics in both the land and in-stream components of river catchments while minimising data requirements and model structural complexity (Wade et al., 2002a). The model structure is appropriate to the problem of quantifying the timing and load of P delivered to river-systems; P transport is highly variable in space and time, and such transportation is often dominated by storm-events. INCA-P is designed to simulate $\mathrm{P}$ transport during storms by considering saturation-excess overland-flow, throughflow and groundwater flow-paths, and also incorporates in-stream processes to account for internal P loads (e.g. historic P inputs from effluent); the latter must be considered when assessing the impact of diffuse $\mathrm{P}$ sources on the aquatic ecology. INCA-P aims to extend current research and is designed to investigate (1) the transport and retention of $\mathrm{P}$ in the terrestrial and aquatic environment, and (2) the relative contributions to the instream $\mathrm{P}$ of external-diffuse, external-point and internal sources (e.g. P release from sediments and decaying organicmatter).

INCA-P builds on the established Integrated Nitrogen in Catchments Model (INCA) which is a dynamic, processbased hydrochemical model that has been used to simulate nitrogen in river systems and plot studies throughout Europe (Neal, 2002; Wade and Neal, 2004), and the 'Kennet' model which simulates in-stream $\mathrm{P}$ and macrophyte/epiphyte dynamics (Wade et al., 2001; Wade et al., 2002b). As such, INCA-P represents an advance towards a generalised framework for simulating water quality determinands in heterogeneous river systems which started with the INCA model. The 'Kennet' model has been used previously to investigate management options, such as the impacts of flow and the removal of $\mathrm{P}$ from effluent on macrophyte biomass (Wade et al., 2002c, d; Wade et al., 2004), and INCA-P was used to assess the integrated effects of variable hydrological connectivity, soil $\mathrm{P}$ conditions and bio-solid applications (Hewett et al., 2004).

The input fluxes that the INCA-P model takes into account are inorganic-P fertiliser and farmyard manure (FYM), slurry applications and livestock wastes. Various output fluxes (plant uptake, movement of labile P to forms that are not taken up by plants or which are bound to organic complexes by microbial immobilisation or become inactive due to chemical immobilisation) are subtracted from these inputs before the amount available for stream output is calculated. These inputs and outputs are differentiated by land-use type and varied according to environmental conditions (e.g. soil moisture and temperature). The model accounts for stocks of inorganic and organic $\mathrm{P}$ in the soil (in readily available and firmly bound forms) and in groundwater; total $\mathrm{P}$ and soluble-reactive $\mathrm{P}$ concentrations are simulated in the stream.

The model simulates the flow of water through the plant/ soil system from different land-use types to deliver the $\mathrm{P}$ load to the river system. This is then routed downstream after accounting for direct effluent discharges and in-stream biological and sediment interactions. As such, the INCA-P model produces daily estimates of discharge, and stream water total P (TP) and soluble reactive P (SRP) concentrations and fluxes at discrete points along a river's main channel. Because the model is semi-distributed, spatial variations in land use and management can be taken into account, although the hydrological connectivity of different land-use patches is not modelled as in a fully distributed approach such as SHETRAN (Birkenshaw and Ewen, 2000). Instead, the hydrological and nutrient fluxes from different land-use classes and sub-catchment boundaries are modelled simultaneously, and information is fed sequentially into a multi-reach river model.

\section{Model set-up and calibration}

The model was set up and calibrated for the period 1 January 1995 to 31 December 2000. These dates were chosen since they covered the period of available flow, water quality and hydrological data. Twenty-two reaches were defined for the application of INCA-P to the Lugg system; the subcatchments are shown in Fig. 1 and described in Table 2. Eight reach boundaries were chosen to coincide with the locations of the hydrochemical sampling sites, and three to coincide with the flow gauging stations. The remaining reaches coincide with reaches defined as part of a SIMCAT modelling exercise (Environment Agency, 2004).

$\mathrm{P}$ application rates for the six INCA-P land-use classes were taken from Johnes and Butterfield (2003), who applied the Export Coefficient Method (ECM) to sub-catchments of the Wye and Hampshire Avon as part of PSYCHIC. The application rates $\left(\mathrm{kg} \mathrm{P} \mathrm{ha}^{-1} \mathrm{a}^{-1}\right)$ were differentiated by geoclimatic region, and were assumed to account for applications of fertiliser. The P loads to permanent and temporary grassland were calculated separately (because they have different fertiliser input rates in the ECM scheme) and then summed to provide a total input to 'grassland'. These application rates were multiplied by the land-use area in each sub-catchment to provide annual application loads 
Table 2. Reaches and sub-catchments defined in the Lugg system.

\begin{tabular}{|c|c|c|c|c|c|}
\hline Sub-catchment & Name & $\begin{array}{l}\text { Cumulative } \\
\text { area (ha) }\end{array}$ & Grid reference & $\begin{array}{l}\text { Water quality } \\
\text { monitoring }\end{array}$ & $\begin{array}{l}\text { Flow } \\
\text { gauge }\end{array}$ \\
\hline 1 & Monaughty & 30 & SO237682 & $\checkmark$ & \\
\hline 2 & ds Norton Brook & 101 & SO310650 & & \\
\hline 3 & Rossers Bridge & 114 & SO348641 & $\checkmark$ & \\
\hline 4 & Byton & 200 & SO364647 & & $\checkmark$ \\
\hline 5 & ds Lime Brook & 228 & SO379652 & & \\
\hline 6 & Mortimers Cross Bridge & 249 & SO426637 & $\checkmark$ & \\
\hline 7 & ds Main Ditch & 303 & SO501596 & & \\
\hline 8 & Butts Bridge & 340 & SO502588 & & $\checkmark$ \\
\hline 9 & Eaton Bridge & 364 & SO507585 & $\checkmark$ & \\
\hline 10 & us R. Arrow & 367 & SO513573 & $\checkmark$ & \\
\hline 11 & Ford Bridge & 659 & SO509551 & $\checkmark$ & \\
\hline 12 & Hampton Court Bridge & 667 & SO514528 & $\checkmark$ & \\
\hline 13 & ds Humber Brook & 715 & SO522522 & & \\
\hline 14 & ds Bodenham Brook & 742 & SO536511 & & \\
\hline 15 & ds Wellington Brook & 790 & SO511470 & & \\
\hline 16 & Wergins Bridge & 798 & SO528446 & & \\
\hline 17 & ds Moreton Brook & 820 & SO533433 & & \\
\hline 18 & ds Little Lugg & 868 & SO531415 & & \\
\hline 19 & Lugwardine Bridge & 876 & SO546406 & & $\checkmark$ \\
\hline 20 & ds Frome & 1060 & SO560386 & & \\
\hline 21 & Mordiford Bridge & 1062 & SO570374 & $\checkmark$ & \\
\hline 22 & Wye confluence & 1077 & SO565371 & & \\
\hline$\underline{\mathrm{ds}}=$ downstream & & & & & \\
\hline
\end{tabular}

$\left(\mathrm{kg} \mathrm{P} \mathrm{a}^{-1}\right)$ for each land-use type. An estimate of the monthly load was made by distributing the fertiliser load based on the timings observed in a survey of land use and fertiliser practice in the River Ant catchment (Johnes et al., 2003). These monthly loads were converted to a daily application rate $\left(\mathrm{kg} \mathrm{P} \mathrm{ha}^{-1} \mathrm{day}^{-1}\right)$ by dividing the monthly load by the number of days per month and the land-class area within each sub-catchment. Similarly, P input rates per head of livestock (sheep, cattle, pigs, poultry) were taken from Johnes and Butterfield (2003). These rates were multiplied by the number of livestock in each sub-catchment to provide

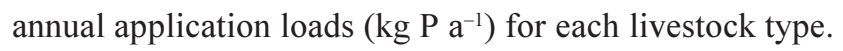
It was assumed that $\mathrm{P}$ inputs from applications of fertiliser and grazing-animals comprised $70 \%$ inorganic and $30 \%$ organic P.

The calculated annual $P$ inputs are shown in Table 3 . The largest inputs are to the 'other arable' land use, and this reflects the higher input rates in the ECM scheme. The input rates from cereal and grassland are approximately constant through the catchment at 9 and $22 \mathrm{~kg} \mathrm{Pha}^{-1} \mathrm{a}^{-1}$, respectively, whereas the input rate to 'other arable' varies between 70 and $90 \mathrm{~kg} \mathrm{P} \mathrm{ha}^{-1} \mathrm{a}^{-1}$.

The annual $\mathrm{P}$ inputs per hectare from grazing livestock are shown in Table 3. The survey of farming in the Ant catchment identified that cattle and sheep predominately grazed grassland, while pigs were found on sugar beet and potatoes. Thus, the $\mathrm{P}$ inputs in the Lugg catchment from cattle and sheep were added to the 'grassland' land class and the $\mathrm{P}$ inputs from pigs to 'other arable'. The input from poultry was also added to 'other arable'. Given an absence of information regarding when and how many head of livestock were housed during winter on the Lugg catchment, it was assumed that all livestock grazed outside for the entire year. The higher inputs from livestock to 'other arable' in the upper reaches of the Lugg are caused by high concentrations of poultry in reaches 1 to 4 , and 9 and 11 . Reach 11 (the River Arrow sub-catchment) also has relatively high numbers of cattle, sheep and pigs. The inputs to grassland vary between approximately 20 and $50 \mathrm{~kg} P$ $\mathrm{ha}^{-1} \mathrm{a}^{-1}$, and the inputs to 'other arable' between 5 and $240 \mathrm{~kg}$ $\mathrm{P} \mathrm{ha}^{-1} \mathrm{a}^{-1}$; the latter appear high and may result from the problems of the limited spatial accuracy of the land use and livestock data caused by adherence to the Non-Disclosure Act whereby a single farm cannot be identified. No livestock manure is assumed to be transported to other catchments; as such the inputs in Table 3 probably represent a maximum 
Table 3. The inputs of $\mathrm{P}\left(\mathrm{kg} \mathrm{P} \mathrm{ha}^{-1} \mathrm{a}^{-1}\right)$ to different land-use types in the Lugg catchment from fertiliser and livestock.

\begin{tabular}{|c|c|c|c|c|c|}
\hline \multirow[b]{2}{*}{ Name } & \multicolumn{3}{|c|}{ Inputs from grazing animals $\left(\mathrm{kg} P \mathrm{ha}^{-1} a^{-1}\right)$} & \multicolumn{2}{|c|}{ Fertiliser applied to the land $\left(\mathrm{kg} P h a^{-1} a^{-1}\right)$} \\
\hline & Grassland & Other arable & Cereal & Grassland & Other arable \\
\hline Monaughty & 34 & 118 & 8 & 23 & 70 \\
\hline ds Norton Brook & 31 & 134 & 8 & 23 & 69 \\
\hline Rossers Bridge & 37 & 103 & 7 & 22 & 89 \\
\hline Byton & 35 & 237 & 8 & 23 & 69 \\
\hline ds Lime Brook & 34 & 28 & 7 & 22 & 89 \\
\hline Mortimers Cross Bridge & 37 & 0 & 7 & 22 & 89 \\
\hline ds Main Ditch & 42 & 33 & 9 & 22 & 83 \\
\hline Butts Bridge & 42 & 38 & 8 & 22 & 89 \\
\hline Eaton Bridge & 36 & 121 & 8 & 22 & 89 \\
\hline us R. Arrow & 23 & 17 & 7 & 22 & 89 \\
\hline Ford Bridge & 36 & 99 & 8 & 23 & 80 \\
\hline Hampton Court Bridge & 33 & 27 & 7 & 22 & 89 \\
\hline ds Humber Brook & 35 & 43 & 7 & 22 & 89 \\
\hline ds Bodenham Brook & 51 & 51 & 8 & 22 & 89 \\
\hline ds Wellington Brook & 41 & 32 & 8 & 22 & 83 \\
\hline Wergins Bridge & 38 & 53 & 7 & 22 & 89 \\
\hline ds Moreton Brook & 49 & 60 & 8 & 23 & 78 \\
\hline ds Little Lugg & 49 & 18 & 8 & 22 & 89 \\
\hline Lugwardine Bridge & 28 & 2 & 8 & 22 & 89 \\
\hline ds Frome & 35 & 12 & 8 & 22 & 89 \\
\hline Mordiford Bridge & 22 & 0 & 7 & 22 & 89 \\
\hline Wye confluence & 17 & 9 & 6 & 22 & 89 \\
\hline
\end{tabular}

annual input of $P$.

MORECS uses an estimate of the growing season for different land-use types to calculate evapotranspiration. These estimates of dates for crop planting and harvest, and tree bud burst and leaf fall across the UK were used to constrain INCA-P. The estimates for square 235, which includes most of the Lugg system, were used (Table 4).

Where estimates were available for a number of different crop types forming part of a single INCA-P land class, the range of dates that incorporated all growing seasons was used. Grass roots are noted as being active all year and, therefore, the growing season was assumed to be year round, with $\mathrm{P}$ uptake rate a function of SMD and soil temperature (Wade et al., 2002b). It was also assumed that set-aside, and parks and gardens within urban areas, behave in this manner. Within INCA-P, it is possible to specify the plant $\mathrm{P}$ uptake rate for each land use; thus, the uptake from grassland, set-aside and urban areas (and all land-use types) can be differentiated.

\section{MODEL CALIBRATION}

The daily MORECS time-series describing the HER, SMD and air temperature from Llandrindod Wells and Madley were used to represent upper reaches 1 to 9, and the lower reaches 10 to 22, respectively (Fig. 4). At Llandrindod Wells, the HER and SMD show that the calibration period from 1 January 1998 to 31 December 2000 was wetter than the period 1 January 1995 to 31 December 1997 . No flow was routed through the direct runoff box, so the application was effectively based on two stores - soil water and groundwater.

To calibrate the hydrological component of INCA-P, the initial flows in the soil water and groundwater boxes for each land-use type were adjusted until the base-flow response closely matched that observed. The Base Flow Index (BFI), which represents the partition between the soil water and groundwater, was obtained from the hydrometric register for the gauges at Byton, Butts Bridge and Lugwardine Bridge (Marsh and Lees, 2003). The residence times in each of the land-use classes were then adjusted such that (1) the residence times of the soil-box controlled the time to peak of the simulated hydrograph and (2) the residence time in the groundwater box controlled the decay of the falling limb. As such, the residence times relate more to lag times between a precipitation event and the peak in the hydrograph and the decay time, rather than a true measure of soil water or a groundwater turnover time. The 
Table 4. Growing seasons used within the INCA-P application to the Lugg system. *Dates are derived from input data used in the MORECS model for MORECS square 235. The dates in bold represent the range used for each INCA-P land class.

\begin{tabular}{|c|c|c|c|}
\hline Land use & ng or bud burst & Harvest or leaf fall & Assumptions \\
\hline Spring barley & 23 Mar & 26 Aug & \\
\hline Winter wheat & $21 \mathrm{Mar}$ & 24 Aug & \\
\hline Winter barley & $11 \mathrm{Mar}$ & 3 Aug & \\
\hline Cereal & 11 Mar & 26 Aug & \\
\hline Early potatoes & $20 \mathrm{Mar}$ & 20 Jun & \\
\hline Main crop potatoes & $15 \mathrm{Apr}$ & 15 Sep* & $\begin{array}{l}\text { Haulm (stems \& stalks) } \\
\text { destruction }\end{array}$ \\
\hline Sugar beet & $1 \mathrm{Apr}$ & 25 Oct & \\
\hline Other arable & 20 Mar & 25 Oct & \\
\hline Grassland & 1 Jan & 31 Dec & Roots active all year \\
\hline Set-aside & 1 Jan & 31 Dec & $\begin{array}{l}\text { Non-rotational, same as } \\
\text { grass }\end{array}$ \\
\hline Deciduous & $22 \mathrm{Apr}$ & 17 Oct & \\
\hline Orchards & 7 May & 27 Sep & \\
\hline Coniferous & - & - & \\
\hline Woodland & 1 Jan & 31 Dec & $\begin{array}{l}\text { Coniferous roots may be } \\
\text { active all year. SMD and } \\
\text { soil temperature control } \\
\text { phosphorus uptake. }\end{array}$ \\
\hline Urban (parks and gardens) & 1 Jan & 31 Dec & All impermeable \\
\hline
\end{tabular}

(a)

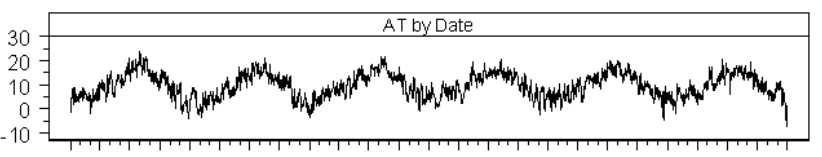

$\mathrm{Q} 1 \mathrm{Q} 2 \mathrm{Q} 3 \mathrm{Q} 4 \mathrm{Q} 1 \mathrm{Q} 2 \mathrm{Q} 3 \mathrm{Q} 4 \mathrm{Q} 1 \mathrm{Q} 2 \mathrm{Q} 3 \mathrm{Q} 4 \mathrm{Q} 1 \mathrm{Q} 2 \mathrm{Q} 3 \mathrm{Q} 4 \mathrm{Q} 1 \mathrm{Q} 2 \mathrm{Q} \mathrm{Q} 4 \mathrm{Q} 1 \mathrm{Q} 2 \mathrm{Q} 3 \mathrm{Q} 4 \mathrm{Q}$

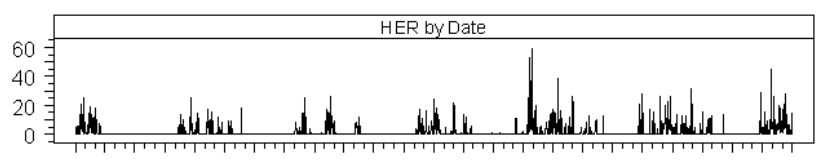

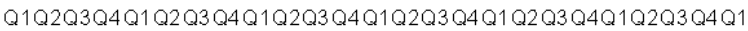

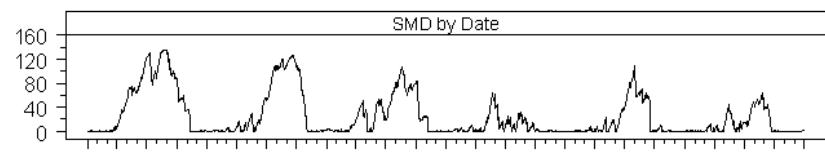

Q1Q2Q3Q4Q1Q2Q3Q4Q1Q2Q3Q4Q1Q2Q3Q4Q1Q2Q3Q4Q1Q2Q3Q4Q1

Date since 01/01/1995 (b)
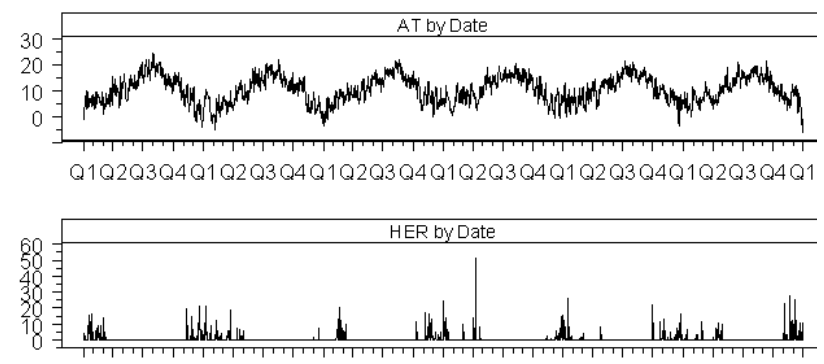

9102Q304Q102Q3040102Q3Q4Q1020304010203040102030401

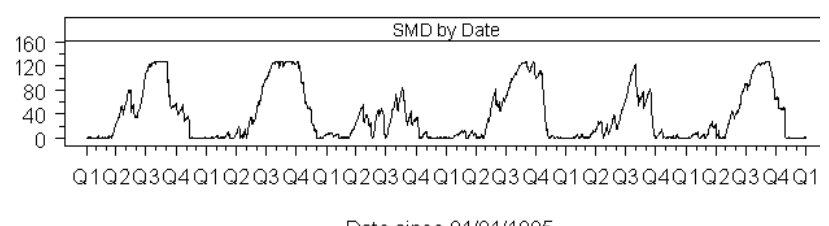

Date since $01101 / 1995$

Fig. 4. Hydrological Effective Rainfall, air temperature and SMD time-series from (a) Llandrindod Wells and (b) Madley for the period 01 January 1995 to 31 December 2000.

initial values of the volumes in the soil water and groundwater boxes were set, based on preconceived notions from geological maps of soil depth and porosity and likely depths of the aquifer. The drainage volume in the soil-box relates to the amount of water in the macropores or drains which is readily able to move and, by a piston effect, most strongly influences the rising hydrograph limb. The soil retention volume represents the water volume stored in the soil that responds more slowly, and may make up the majority of the water storage in the soil (similar to the field capacity concept). This water may be thought of as stored in the micropores.

The relationship between the velocity and the discharge in each reach is specified in Eqn. (24) of Wade et al., 2002a. 
Table 5. Initial TP concentrations $\left(1 / 4 \mathrm{~g} \mathrm{P} \mathrm{l}^{-1}\right)$ in the land-phase of INCA-P applied to the Lugg system.

\begin{tabular}{lcc}
\hline Land use/pathway & Soil water & Groundwater \\
\hline Grassland & 200 & 2 \\
Cereal & 200 & 2 \\
Other arable & 200 & 2 \\
Set-aside & 20 & 2 \\
Woodland & 20 & 2 \\
Urban & 20 & 2 \\
\hline
\end{tabular}

These were calibrated to improve the hydrological fit. The values of $a$ and $b$, together with all the other model parameters, are listed in the Appendix.

The initial TP and suspended sediment concentrations in the land phase of the model were set by calibration. The TP concentrations measured in field experiments were used to set the initial soil TP concentrations (Table 5; Heathwaite and Dils, 2000). No measured groundwater TP concentrations were available.

Only those effluents discharging directly into the main stem of the River Lugg were included in this application (Table 6). Initial simulations suggest that the influence of effluent inputs is not propagated beyond a single INCA-P reach. It is acknowledged that this may be an oversimplification and that further investigation is required to determine the appropriateness of this assumption.

Tertiary $\mathrm{P}$ stripping was applied at Cadburys and at Leominster in 1998 and monthly time-series describing the effluent TP concentrations are available for these two inputs. The other effluent inputs were modelled as constant inputs through the simulation period. The effluent flows were estimated from EA records of the mean effluent flow, the population equivalent (multiplied by $180 \mathrm{~L} \mathrm{day}^{-1}$, or the maximum permissible flow). The mean effluent TP concentration was calculated from time-series data of monthly frequency.

The parameters relating to the land-phase processes of plant uptake and transformation into chemically and biologically inactive $\mathrm{P}$ forms were adjusted in addition to the initial suspended sediment concentrations, and in-stream parameters to improve the fit to the observed streamwater $\mathrm{TP}$ concentrations. The terms relating to mineralisation and immobilisation were not adjusted, as it was assumed that they were in equilibrium. The land-phase plant and crop uptake parameters were also adjusted until the simulated annual output load was within the range specified in the literature.

\section{Results and discussion}

\section{HYDROLOGICAL SIMULATION}

The observed flows show an increasing trend from 1995 to 2001 comparable with the increasing-trend observed in the input HER and SMD time series. The simulated flows match those observed at all three gauging stations (Fig. 5). The 'a' and ' $b$ ' parameters ( 0.04 and 0.67 , respectively, for all reaches) are the same as those used in the application of INCA-N to the River Twyi, a system similar to the Lugg (Whitehead et al., 1998). The structure of in-stream hydrological model in INCA-P is the same as that in INCAN. INCA-P both under- and over-estimates different peak flow events, although the simulation of the base flow recession is good. The results of the three goodness-of-fit tests are presented in Tables 7 and 8 , and these results demonstrate a good hydrological fit at all three gauging stations.

Table 6. Input loads from STWs and trade effluents directly into the main stem of the River Lugg.

\begin{tabular}{|c|c|c|c|c|c|}
\hline Reach & Effluent name & $\begin{array}{l}\text { Population } \\
\text { equivalent }\end{array}$ & Flow & $\begin{array}{l}\text { TP } \\
\text { concentration }\end{array}$ & TP load \\
\hline 1 & Llangunllo & 120 & 0.0003 & 4.69 & 37 \\
\hline 3 & Presteigne & 1851 & 0.0059 & 4.52 & 841 \\
\hline 7 & Lucton & 550 & 0.0019 & 3.63 & 212 \\
\hline 10 & Leominster* & 10854 & 0.0332 & 4.92 & 5145 \\
\hline 12 & Cadburys* & - & 0.0637 & 5.42 & 10881 \\
\hline 14 & Bodenham & 600 & 0.0014 & 7.71 & 338 \\
\hline 16 & Moreton & 2721 & 0.0072 & 9.45 & 2139 \\
\hline 21 & Mordiford (Sufton) & 1) 134 & 0.0003 & 15.60 & 137 \\
\hline
\end{tabular}



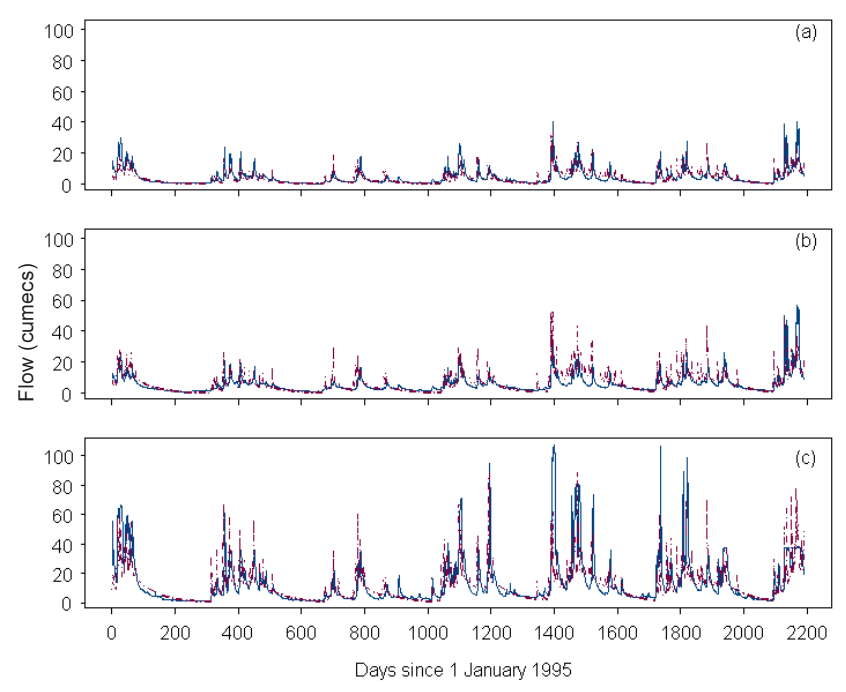

Fig. 5. Simulated and observed flows at (a) Byton (reach 4), (b) Butts Bridge (reach 8) and (c) Lugwardine Bridge (reach 19).

Table 7. Nash-Sutcliffe coefficient for the simulations flow, TP and suspended sediment in reaches along the Lugg system (Nash and Sutcliffe, 1970). Correlation coefficient is given in brackets.

\begin{tabular}{llll}
\hline Reach & $\begin{array}{l}\text { Flow } \\
\left(m^{3} s^{-1}\right)\end{array}$ & $\begin{array}{l}T P \\
\left(m g P l^{-1}\right)\end{array}$ & $\begin{array}{l}S S \\
\left(m g l^{-1}\right)\end{array}$ \\
\hline Byton & $0.58(0.76)$ & - & - \\
Butts Bridge & $0.36(0.60)$ & - & - \\
Hampton Court Bridge & - & $<0$ & $0.28(0.52)$ \\
$\begin{array}{l}\text { Lugwardine Bridge } \\
\text { Mordiford Bridge }\end{array}$ & $0.47(0.69)$ & - & - \\
\hline
\end{tabular}

Table 8. Explained variance for flow, TP and suspended sediment in reaches along the Lugg system.

\begin{tabular}{llll}
\hline Reach & $\begin{array}{l}\text { Flow } \\
\left(m^{3} s^{-1}\right)\end{array}$ & $\begin{array}{l}\text { TP } \\
\left(m g P l^{-1}\right)\end{array}$ & $\begin{array}{l}S S \\
\left(m g l^{-1}\right)\end{array}$ \\
\hline Byton & 0.59 & - & - \\
Butts Bridge & 0.38 & - & - \\
Hampton Court Bridge & - & $<0$ & 0.29 \\
$\begin{array}{l}\text { Lugwardine Bridge } \\
\text { Mordiford Bridge }\end{array}$ & 0.48 & - & - \\
\hline
\end{tabular}

\section{SIMULATION OF IN-STREAM P AND SUSPENDED SEDIMENT CONCENTRATIONS}

The simple mixing model approach that forms the basis of INCA-P was able to reproduce the spatial and temporal variations of the in-stream TP and suspended sediment dynamics to a first approximation (Figs. 6-8; Tables 7 and 8 ). The model is able to simulate the observed TP concentrations better in the lower reaches, which are dominated by point-sources. In reach 1 in the headwaters at Monaughty, the influence of diffuse sources is most apparent in the observed stream water TP concentrations. For reach 1, the simulated stream TP concentrations are the poorest fit of those observed, probably due to the complexity of capturing the response of the highly heterogeneous source areas and flow path activation which may have a fractal character which is not simulated-well by 'bucket' models like INCA-P (Kirchner et al., 2000; 2001). In particular, the observed base flow concentrations tend to be overestimated, indicating that the retention of $\mathrm{P}$ in the soil, groundwater or stream system is under-estimated. At present it is unclear if further data regarding the internal structure of the catchment such as groundwater or soil-water samples will help to identify the optimum structure of model and parameter-set; such data may only highlight the heterogeneity of the system (Beven, 2000).

Further down the main channel of the Lugg, at Hampton Court Bridge and Mordiford Bridge, the simulated in-stream $\mathrm{TP}$ concentrations match those observed well. In these reaches, the system is simpler to model; the $\mathrm{P}$ dynamics are dominated by the dilution of point source inputs. At these two sites, the model is able to reproduce the general downward trend in the observed time-series of stream water TP concentrations from 1995 to 2000. At Hampton Court Bridge, the reach receives effluent from Leominster STW. The observed decrease in TP (and TRP) is, therefore, partly due to the removal of $\mathrm{P}$ from the final effluent. However, the higher flows in 1999 and 2000 increased the dilution capacity at a time when the effluent concentration from Leominster (and Cadburys) was lower. The over-estimation of the in-stream TP concentrations in 1995 is most probably due to the under-estimation of the flow in the reach during the summer.

The observed mean streamwater TP concentrations also highlight the effect of point source contributions along the longitudinal profile of the Lugg. In the headwaters, the low background $\mathrm{P}$ concentrations from diffuse sources are modified by small point source contributions in reaches 1 and 3 (Fig. 8). Downstream of Eaton Bridge, both the mean observed and simulated TP concentrations increase; the

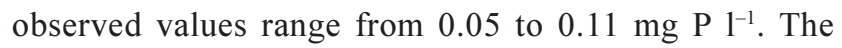
observed and simulated mean TP concentrations then increase further due to the cluster of point source in reaches 10 to 12 , which include Leominster STW and Cadburys, to a concentration of approximately $0.17 \mathrm{P}^{-1}$. Due to the lack of observations between Hampton Court Bridge and Mordiford Bridge, it is difficult to determine whether the 


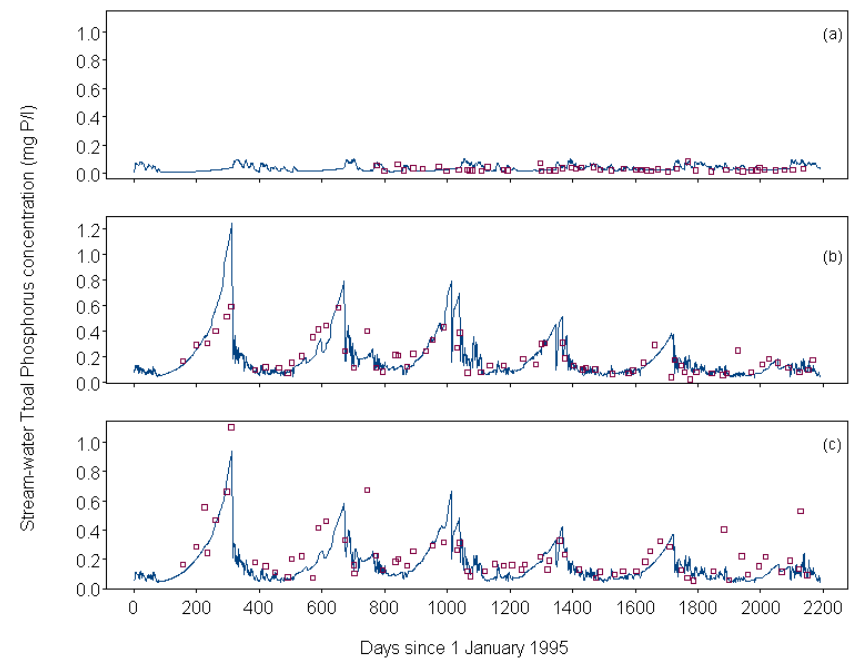

Fig. 6. Simulated and observed stream-water TP concentrations at (a) Monaughty (reach 1), (b) Hampton Court Bridge (reach 12) and (c) Mordiford Bridge (reach 21).

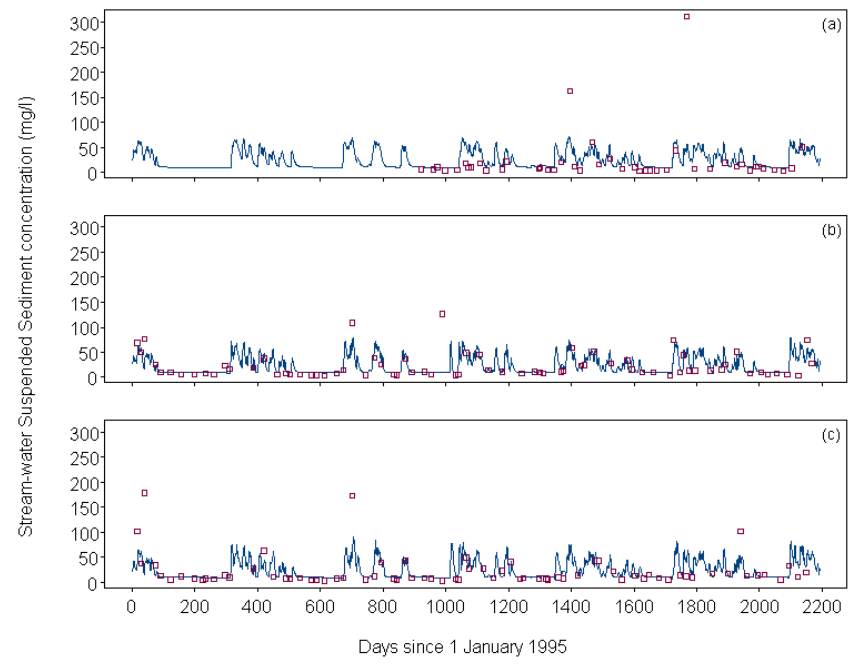

Fig. 7. Simulated and observed stream-water suspended-sediment concentrations at (a) Monaughty (reach 1), (b) Hampton Court Bridge (reach 12) and (c) Mordiford Bridge (reach 21). simulated variations in the mean concentrations are reasonable. Observations suggest an increase in concentration in the lower reaches. However, the simulated data between these two sample sites suggest possible dilution. The simulated summer flows tend to be over-estimated at Lugwardine Bridge when compared with observations, possibly resulting in an over-dilution of the point source contributions. There are three alternative reasons for this. Firstly, a point source discharging directly into the lower reaches may have been omitted or under-estimated. Secondly, the influence of the point sources on the Frome needs to be included or the downstream influence of the effluent inputs at Leominster, Bodenham and Moreton STWs, and Cadburys extends down the reach. Thirdly, the diffuse source input has been under-estimated in the lower reaches.

At present, due to structural and parameter equifinality, it is not possible to determine the reason for the point-source contributions without additional data or knowledge. Both the observed and simulated stream water TP concentrations indicate a threshold between two sections of the Lugg. Upstream of the confluence with the River Arrow, the Lugg

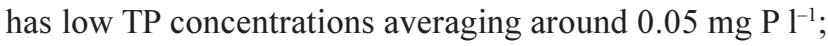
downstream in the area of greater urbanisation and agricultural intensification, the stream water concentrations are higher, averaging around $0.16 \mathrm{mg} \mathrm{P}^{-1}$. The mean simulated SRP concentrations are almost identical in the water column and stream bed, suggesting an equilibrium over the period studied. Given the uncertainty in the identification of the most appropriate model structure, then it is recommended that all combinations of model structure and parameter-sets which are able to reproduce the observations are used for forecasting the stream-water response to climate and/or land-management change (Beven, in press).

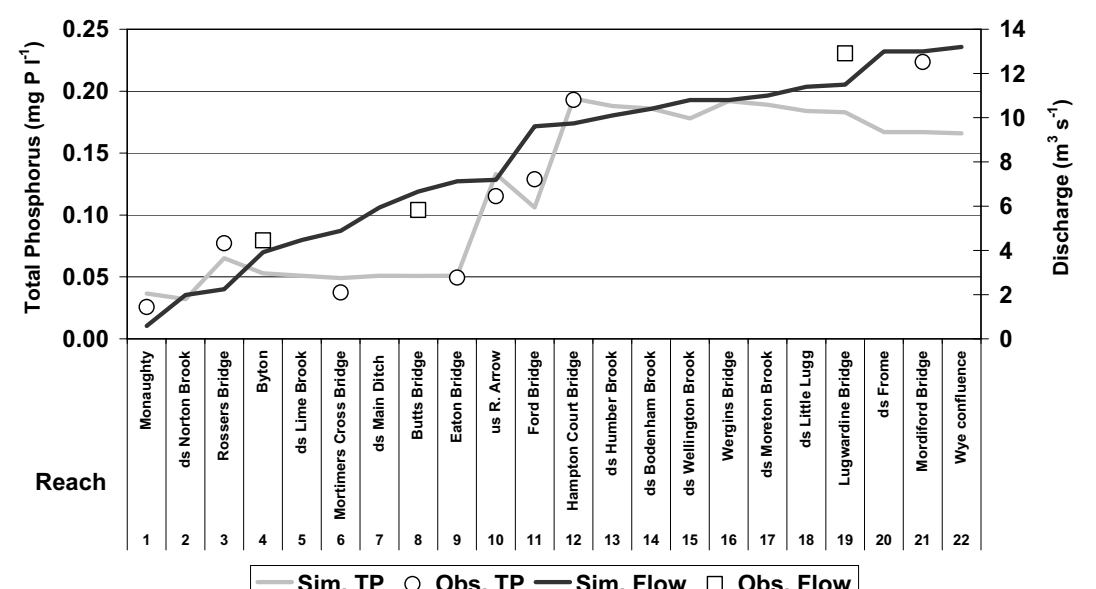

Fig. 8. Simulated and observed mean flow and TP concentrations along the River Lugg over the period 1995 to 2000. 


\section{MACROPHYTE AND EPIPHYTE GROWTH}

No data were available to describe the macrophyte and epiphyte biomass in terms of carbon mass per plant surface area $\left(\mathrm{g} \mathrm{C} \mathrm{m}^{-2}\right)$ within the Lugg system and, therefore, the model's ability to simulate macrophyte and epiphyte growth was not tested in terms of reproducing observed biomass estimates. However, the model behaviour was found to simulate sine-wave growth and death of macrophytes and epiphytes. The lack of biomass estimates, though a problem in this study, raises the question of how can good ecological status be assessed? Modellers need to know what the key indicator species are so that appropriate models can be developed.

\section{LAND PHASE AND IN-STREAM TP LOADS}

The annual loads ( $\left.\mathrm{kg} \mathrm{P} \mathrm{ha}^{-1} \mathrm{a}^{-1}\right)$ of TP exported from different land uses are generally within the range reported in the literature for UK and USA river systems and plot experiments (Table 9). Apart from plant uptake from grassland in the upper reaches, both the simulated $\mathrm{P}$ plant uptake and export rates are at the lower end or below the range of the observed data. A mass-balance on the $\mathrm{P}$ input to the land phase suggested that only $1 \%$ of the $\mathrm{P}$ input to the land reaches the water column; the remaining $99 \%$ is stored either in the soil, the groundwater or in the stream bed sediments. To calibrate the model to the observed stream-water $\mathrm{P}$ data, much of the $\mathrm{P}$ input to the system was simulated as being retained in the soil.

\section{UPLAND AND LOWLAND IN-STREAM P LOADS}

A comparison of the point source loads with those exported from the different land-use types included in INCA-P is shown in Fig. 9. These data exhibit the same threshold as the mean observed stream water TP concentrations: the profile can be divided into two sections above and below Eaton Bridge. In the upper reaches, the ratio of load contribution from point and all diffuse sources is 1:9 and, in the lower reaches, the ratio is $1: 1$.

The model simulations identify that spatial-variations in the precipitation are important in relation to determining the amount of $\mathrm{P}$ exported from the land to the stream: export rates $\left(\mathrm{kg} \mathrm{P} \mathrm{ha}^{-1} \mathrm{a}^{-1}\right)$ are greater in the wetter uplands. In the uplands, the key P source-areas are cereal and grassland in terms of annual $\mathrm{P}$ export per hectare and total export respectively; in the lowlands, cereal is also key in terms of export per hectare, and as important as grassland in terms of total export.

\section{THE INFLUENCE OF THE RIVER LUGG ON THE RIVER WYE}

The influence of the River Lugg on the River Wye was determined by comparing the simulated SRP load delivered from the Lugg to the Wye with the observed TRP load at Redbrook on the Wye, which is the lowest gauging station (Jarvie et al., 2003); INCA-P does not simulate TRP, and TP measurements for the Wye at Redbridge were not published in Jarvie et al., 2003. Though TRP and TP are not directly comparable, the comparison still provides an indication of when the Lugg was contributing more to the P-load in the Wye. Between 1995 and 2000, the Lugg contributed at least $13-35 \%$ of the TRP load estimated in the Wye (Table 10). The greatest influence occurred in 1996, and this year was the driest year considered and predated $\mathrm{P}$ stripping at Cadburys and Leominster. Thus, in drier years,

Table 9. Comparison of simulated and observed process loads ( $\left.\mathrm{kg} \mathrm{P} \mathrm{ha-1} \mathrm{a}^{-1}\right)$ from UK and US studies.

\begin{tabular}{|c|c|c|c|c|}
\hline Process & ub-catchment 1 & Sub-catchment 12 & Sub-catchment 21 & Observed range \\
\hline \multicolumn{5}{|l|}{ CROP UPTAKE } \\
\hline Cereal & 15 & 15 & 15 & $19-27^{1}$ \\
\hline Other arable & 20 & 11 & 8 & $14-21^{1}$ \\
\hline Grassland & 12 & 10 & 7 & $12-40^{2,3}$ \\
\hline \multicolumn{5}{|l|}{ TP EXPORT } \\
\hline Cereal & 0.84 & 0.34 & 0.34 & $0.07-7.5$ \\
\hline Other arable & 0.72 & 0.18 & 0.14 & $0.07-7.5$ \\
\hline Grassland & 0.32 & 0.12 & 0.09 & $0.2-9.7$ \\
\hline Woodland/forest & 0.03 & 0.02 & - & $0.007-0.9$ \\
\hline Urban & - & 0.02 & 0.02 & $0.9-3.4$ \\
\hline
\end{tabular}




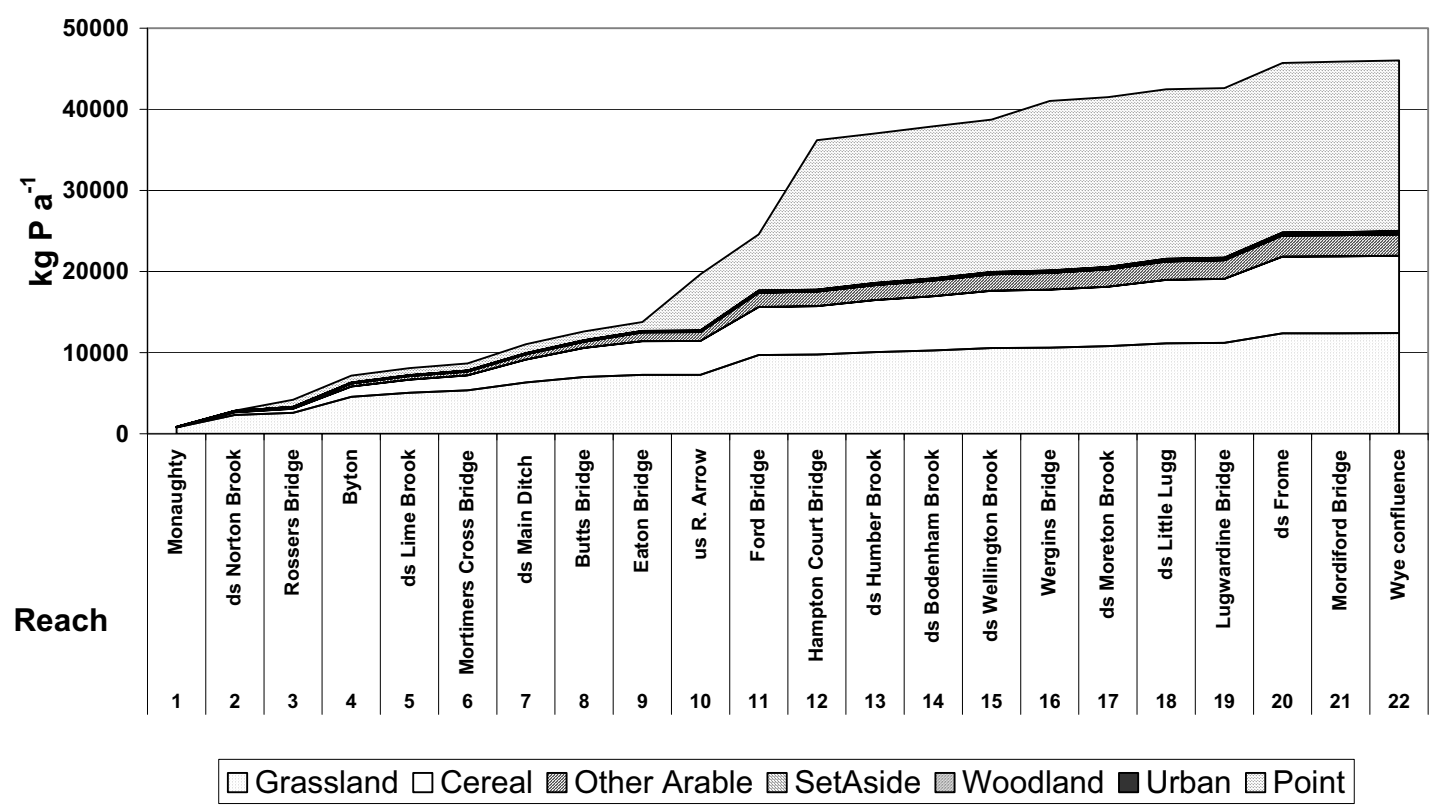

Fig. 9. Simulated cumulative load $\left(\mathrm{kg} P \mathrm{a}^{-1}\right)$ exported from the land to the river in the Lugg catchment compared with the point source load.

Table 10. Comparison of SRP loads $\left(\mathrm{kg} \mathrm{P} \mathrm{a}^{-1}\right)$ calculated from INCA-P simulations in the Lugg and TRP load-estimates calculated from TRP concentrations measured in the Wye at Redbrook (Jarvie et al., 2003).

\begin{tabular}{|c|c|c|c|c|c|}
\hline \multirow[t]{2}{*}{ Year } & \multicolumn{2}{|c|}{ Precipitation $\left(\mathrm{mm} \mathrm{a}^{-1}\right)$} & \multicolumn{2}{|c|}{ Load (tonnes $P a^{-1}$ ) } & \multirow[t]{2}{*}{ Impact of Lugg (\%) } \\
\hline & Llandridod Wells & Madley & $\begin{array}{l}\text { Lugg at confluencewith Wye } \\
\text { SRP }\end{array}$ & $\begin{array}{l}\text { Wye at Redbrook } \\
\text { TRP }\end{array}$ & \\
\hline 1995 & 993 & 774 & 33 & 171 & 19 \\
\hline 1996 & 876 & 648 & 27 & 77 & 35 \\
\hline 1997 & 921 & 785 & 33 & 230 & 14 \\
\hline 1998 & 1409 & 806 & 39 & 306 & 13 \\
\hline 1999 & 1352 & 797 & 36 & 220 & 16 \\
\hline 2000 & 1380 & 799 & 33 & 247 & 13 \\
\hline
\end{tabular}

the point sources in the Lugg had more of an impact on the Wye. Following $\mathrm{P}$ stripping and during wetter years, the influence was less.

\section{IN-STREAM P UPTAKE AND RELEASE}

The uptake and release from sediments and plants in each reach was assessed by mass balance (Table 11). Specifically, the change in P stored in each reach was calculated over the study period using the following equation:

$$
\Delta S=I_{U}+I_{D}+I_{P}-O
$$

where: $\Delta S$ is the change in $\mathrm{P}$ stored in the period $(\mathrm{kg} \mathrm{P}), I_{U}$, $I_{D}, I_{P}$ are the input $\mathrm{P}$ loads $(\mathrm{kg} \mathrm{P})$ from upstream, diffuse and point sources, respectively and $O$ is the output load $(\mathrm{kg} \mathrm{P})$.
The change in storage within each reach is a very small percentage, approximately 0.01 per cent of the TP output from each reach over a year. This result suggests that, on the reach scale of the INCA-P model (500 to 10000 metres), $P$ is neither gained nor lost over an annual-cycle nor are any changes significant at the scale of the reaches used in the model application. This result needs further verification using the measurements made as part of the PSYCHIC project; P-sediment exchanges may not be in equilibrium at smaller spatial-scales, such as localised impacts of STW effluent inputs.

\section{IN-STREAM EFFECTS OF P REMOVAL FROM STW EFFLUENT}

Given the importance of point source inputs within the Lugg 
Table 11. The simulated uptake and release of phosphorus in the reaches of the River Lugg.

\begin{tabular}{|c|c|c|c|c|c|c|}
\hline Reach & Output (kg P) & Upstream (kg P) & Diffuse ( $k g P$ ) & Point (kg P) & $\Delta S(k g P)$ & Uptake or release \\
\hline 1 & 896 & 0 & 850 & 37 & -10 & Release \\
\hline 2 & 2877 & 896 & 1977 & 0 & -4 & Release \\
\hline 3 & 4215 & 2877 & 500 & 841 & 3 & Uptake \\
\hline 4 & 7205 & 4215 & 2990 & 0 & 0 & Equilibrium \\
\hline 5 & 8111 & 7205 & 910 & 0 & 5 & Uptake \\
\hline 6 & 8698 & 8111 & 581 & 0 & -6 & Release \\
\hline 7 & 11056 & 8698 & 2142 & 212 & -5 & Release \\
\hline 8 & 12623 & 11056 & 1583 & 0 & 17 & Uptake \\
\hline 9 & 13786 & 12623 & 1164 & 0 & 1 & Uptake \\
\hline 10 & 19673 & 13786 & 39 & 5844 & -4 & Release \\
\hline 11 & 24582 & 19673 & 4916 & 0 & 7 & Uptake \\
\hline 12 & 36200 & 24582 & 131 & 11487 & 0 & Equilibrium \\
\hline 13 & 37032 & 36200 & 830 & 0 & -3 & Release \\
\hline 14 & 37912 & 37032 & 549 & 338 & 6 & Uptake \\
\hline 15 & 38678 & 37912 & 803 & 0 & 37 & Uptake \\
\hline 16 & 41013 & 38678 & 161 & 2139 & -35 & Release \\
\hline 17 & 41475 & 41013 & 461 & 0 & -1 & Release \\
\hline 18 & 42480 & 41475 & 986 & 0 & -18 & Release \\
\hline 19 & 42610 & 42480 & 134 & 0 & 4 & Uptake \\
\hline 20 & 45712 & 42610 & 3114 & 0 & 12 & Uptake \\
\hline 21 & 45908 & 45712 & 37 & 137 & -21 & Release \\
\hline 22 & 46049 & 45908 & 136 & 0 & -4 & Release \\
\hline
\end{tabular}

catchment and the better simulations of in-stream TP concentrations influenced by effluent-inputs, two scenarios were examined to explore the potential effects of adding $P$ stripping to all the effluents listed in Table 6.

- The first scenario is the removal of all $\mathrm{P}$ from point sources. This is an extreme case and unlikely ever to be implemented, yet it allows the effects of the diffuse sources alone to be examined.

- The second scenario is the reduction of the effluent TP concentration to $1 \mathrm{mg} \mathrm{Pl}^{-1}$. This concentration is typical of what has been achieved at Cadburys and Leominster following P stripping.

For each scenario, the model was run for the period 1 January 1995 to 31 December 2000 to simulate a range of hydrological conditions. The mean and maximum simulated SRP concentrations were calculated for the months June, July and August over the simulation period. These months correspond to the summer low flows, which have been suggested as the period when the in-stream ecology is most sensitive to SRP concentrations (Neal and Jarvie, 2005).

Removing the point-source contribution entirely alters the relationship between flow and in-stream TP concentration (Fig. 10). As was to be expected, the pattern of effluent concentration during the summer and dilution in spring and autumn is replaced by a pattern typical of diffuse source domination, i.e. higher $\mathrm{P}$ concentrations during storm events, with the highest concentrations occurring during the first autumnal storms. In summer, the simulated stream water TP concentrations fall to zero due to the lack of point source input and as no $\mathrm{P}$ is transported from the land to the river

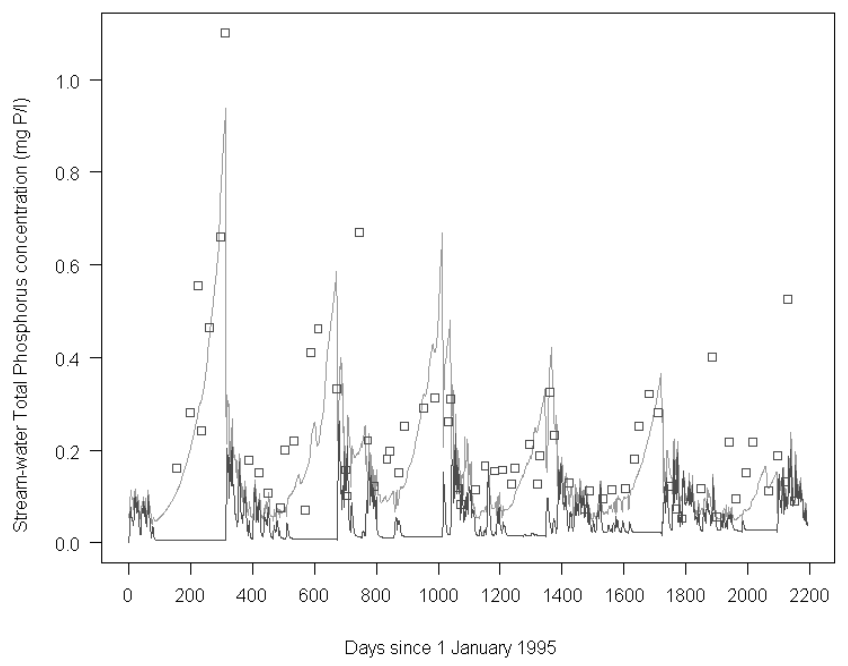

Fig. 10. Simulated effect on the stream water TP concentrations at Mordiford Bridge of removing all P from the effluents discharging into the River Lugg. 
due to the simulated $\mathrm{P}$ sorption on soils and plant uptake from the soils and stream. This is unlikely to occur in reality and suggests that the simulation of in-stream $\mathrm{P}$, uptake $\mathrm{P}$, release from bed sediments $\mathrm{P}$, sorption to soils $\mathrm{P}$ and $\mathrm{P}$ transport via flow-pathways requires further work.

Both scenarios result in simulated mean and maximum stream water SRP concentrations at, or below, the values calculated when the observed effluent discharges were used for model calibration (Fig. 11). The reduction in the mean and maximum concentrations is greatest in lower reaches, which receive more effluent than the upper reaches. Removing all the $\mathrm{P}$ from effluent results in simulated mean SRP concentrations below $60 \mu \mathrm{g} \mathrm{P} \mathrm{P}^{-1}-$ a threshold used to define eutrophic status (in lakes) in terms of SRP and suggested by Neal and Jarvie (2005) as a potentially useful threshold for rivers. Following the simulated reduction in effluent concentration to $1 \mathrm{mg} \mathrm{P}^{-1}$, the simulated mean SRP concentration ranges from 15 to $38 \mu \mathrm{g} \mathrm{P}^{-1}$ in the lower reaches. The simulated maximum concentrations also fall, although these are still above the $60 \mu \mathrm{g} \mathrm{P} \mathrm{l}^{-1}$ threshold; they range from 31 to $65 \mu \mathrm{g} \mathrm{P}^{-1}$ in the upper and lower reaches, respectively.

\section{Conclusions}

Through data analysis, coupled with using INCA-P as a learning tool, the application of the model to the Lugg river system has provided important information on:

- The location of 'P-rich' areas within the catchment. The maps of TP concentrations indicate that the lower reaches of the Lugg, the River Frome and Stretford Brook have the highest stream-water TP concentrations. The maps also highlight the key point-sources. Given the predominance of grassland in the catchment, this is the main diffuse source in terms of total load, though
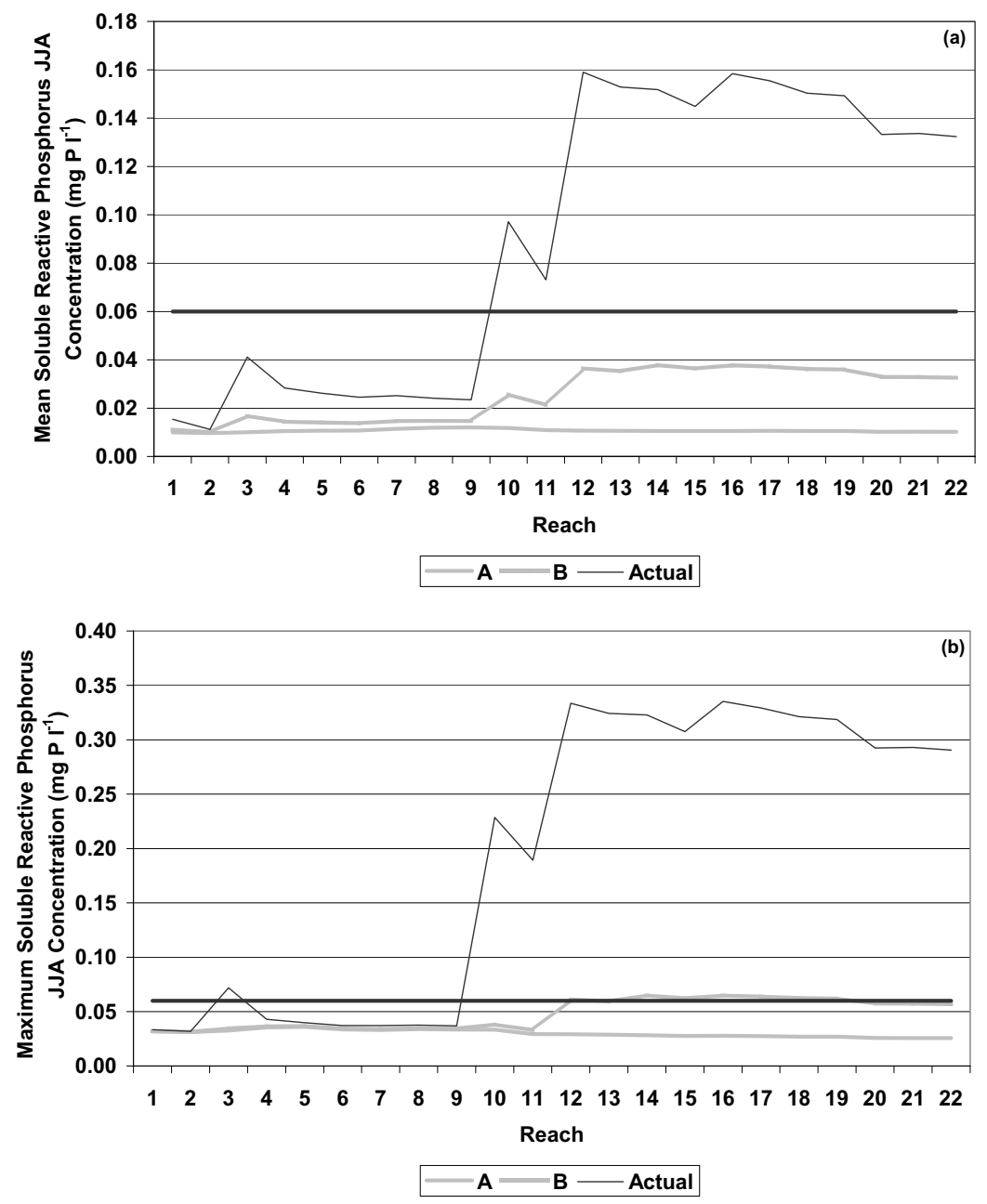

Fig. 11. Simulated effect on the (a) mean and (b) maximum stream water SRP concentrations during June, July and August (JJA) from 1995 to 2000 of reducing the effluent concentration to 0 and $1 \mathrm{mg} \mathrm{P}^{l^{-1}}$ in point discharges to the River Lugg. 
cereal is important in terms of annual $\mathrm{P}$ export per hectare. It is difficult to pin-point $\mathrm{P}$ hot-spots given the uncertainty in the input Agricultural Census which is modified under the Non-Disclosure Act to prevent the identification of individual farms. Better spatial accuracy of land use and livestock statistics and more frequent measurements of flow and TP and SRP concentrations of the final effluent from STWs are required to improve the $\mathrm{P}$ mass-balance at a catchmentscale.

- The upland/lowland contrast within the system which is manifest in terms of greater TP loads from diffuse sources in the uplands associated with higher precipitation, and larger and more effluent inputs in the lower reaches of the Lugg.

- The Lugg contributes more TP to the load in the Wye during dry years due to the number of point sources in the Lugg.

- At reach scales of approximately $10000 \mathrm{~m}$ over a timeperiod of five years, the model simulations suggest that the P-balance is in equilibrium with no net adsorption or de-adsorption to or from bed sediment.

The results also indicate the importance of the point source contribution to the in-stream $\mathrm{P}$ load in the lower reaches of the Lugg. Preliminary scenarios suggest that further P stripping may further reduce the mean stream water SRP concentration close to $60 \mu \mathrm{g} \mathrm{P}^{-1}$ during the summer months. However, further work is needed to verify this result using SRP data from the PSYCHIC project and to understand the potential ecological implications and likely costs. The utility of combining a detailed dataset with a medium-complexity model for learning about the P dynamics of the catchment has been demonstrated and has shown that at larger spatial $\left(>50 \mathrm{~km}^{2}\right.$ ) and (seasonal and inter-annual) temporal scales readily-available land-use and hydrological data can be used to simulate in-stream P loads (Wade et al., 1999, 2000). Further work is required to improve the simulation of $\mathrm{P}$ dynamics at the daily time-step in areas where diffuse inputs from multiple source areas and flow-pathways predominate. In particular, this model-based assessment must be refined as new data and process-understanding are gained. SolubleReactive $\mathrm{P}$ data are needed to understand the relative inputs of particulate and soluble $P$ from sewage and agricultural sources and the impacts of each of these on the in-stream $P$ cycle. Labelling the P from effluent and agricultural sources within simulation models and tracking its movement may aid the debate on the relative effects of effluent and agriculture on in-stream ecological health. It is unclear if such data will provide a useful description of the internal dynamics of the catchment or only highlight the heterogeneity of the factors and processes controlling Pcycling and transport. A more fruitful approach might be the collection of long-term, high-frequency, multi-channel (chemical determinand) data (Kirchner et al., in press).

\section{Acknowledgements}

This research was funded by the Environment Agency Science Project P2-137.

\section{References}

Beven, K.J., 2000. Uniqueness of place and process representations in hydrological modelling. Hydrol. Earth Syst. Sci., 4, 203213.

Beven, K., 2006. A manifesto for the equifinality thesis. J. Hydrol. In press.

Birkenshaw, S.J. and Ewen, J., 2000. Nitrogen transformation component for SHETRAN catchment nitrate transport modelling. J. Hydrol., 230, 1-17.

Brookes, P.C., Powlson, D.S. and Jenkinson, D.S., 1984. Phosphorus in the soil microbial biomass. Soil Biol. Biochem., 16, 169-175.

Environment Agency, 2004. Wye \& Lugg Habitats Directive Water Quality Investigation Project, SIMCAT Model Build Final Report TE205. Environment Agency, Cardiff, UK.

Foy, R.H., Tunney, H., Carroll, M.J., Byrne, E., Gately, T., Bailey, J.S. and Lennox, S.D., 1997. A comparison of Olsen and Morgan soil phosphorus test results from the cross-border region of Ireland. Irish J. Agr. Food Res., 36, 185-193.

Gustard, A., Bullock, A. and Dixon, J.M. 1992. Low flow estimation in the United Kingdom 1992. Institute of Hydrology Report No. 108, Institute of Hydrology, Wallingford, UK.

Hewett, C.J.M., Quinn, P.F., Whitehead, P.G., Heathwaite, A.L. and Flynn, N.J., 2004. Towards a nutrient export risk matrix approach to managing agricultural pollution at source. Hydrol. Earth Syst. Sci., 8, 834-845.

Hough, M., Palmer, S., Weir, A., Lee, M. and Barrie, I. 1997. The Meteorological Office Rainfall and Evaporation Calculation System: MORECS Version 2.0 (1995) 1997. Meteorological Office, Bracknell, UK.

Jarvie, H.P., Neal, C., Williams, R.J., Neal, M., Wickham, H., Hill, L.K., Wade, A.J., Warwick, A. and White, J., 2002. Phosphorus sources, speciation and dynamics in a lowland eutrophic Chalk river; the River Kennet, UK. Sci. Total Envir., 282/283, 353-373.

Jarvie, H.P., Neal, C., Withers, P.J.A., Robinson, A. and Salter, N., 2003. Nutrient water quality of the Wye catchment, UK: exploring patterns and fluxes using the Environment Agency archives. Hydrol. Earth Syst. Sci., 7, 722-743.

Johnes, P.J. and Butterfield, D., 2003. Export coefficient model runs for the Hampshire Avon and the Herefordshire Wye catchments, based on $1 \mathrm{~km}^{2}$ grid scale data from the 1995 Annual Agricultural Census returns. Aquatic Environments Research Centre, University of Reading, Reading, UK.

Johnes, P.J., Whitehead, P.G., Davies, S., Wade, A.J. and Butterfield, D., 2003. Effectiveness of eutrophication control by phosphorus reduction. Aquatic Environments Research Centre, University of Reading, UK.

Kirchner, J.W., Feng, X. and Neal, C., 2000. Fractal stream chemistry and its implications for contaminant transport in catchments. Nature, 403, 524-527. 
Kirchner, J.W., Feng, X., Neal, C. and Robson, A. J., 2001. Catchment-scale advection and dispersion as a mechanism for fractal scaling in stream tracer concentrations. J. Hydrol., 254, 81-100.

Kirchner, J.W., Feng, X., Neal, C. and Robson, A., 2006. The fine structure of water-quality dynamics: the (high-frequency) wave of the future. J. Hydrol. In press.

Lord, E.I. and Anthony, S.G., 2000. MAGPIE. A modelling framework for evaluating nitrate losses at national and catchment scales. Soil Use Manage., 16, 167-174.

Mainstone, C.P., Parr, W. and Day, M., 2000. Phosphorus and river ecology: tackling sewage inputs. English Nature, Peterborough, UK. 46pp.

Marsh, T.J and Lees, M. L. (Eds.)., 2003. Hydrological Data United Kingdom, Hydrometric Register and Statistics 19962000. Centre for Ecology and Hydrology, Wallingford, UK. 208pp.

Moore, R.V., Morris, D.G. and Flavin, R.W. Sub-set of UK digital 1:50 000 scale river centre-line network. 1994. NERC, Institute of Hydrology, Wallingford, UK.

Neal, C. and Jarvie, H.P., 2005. Agriculture, community, river eutrophication and the Water Framework Directive. Hydrol. Process., 19, 1895-1901.

Neal, C., Jarvie, H.P., Wade, A.J., Neal, M., Wyatt, R., Wickham, H., Hill, L. and Hewitt, N., 2004. The water quality of the LOCAR Pang and Lambourn catchments. Hydrol. Earth Syst. Sci., 8, 614-635.

Sharpley, A. 1995. Identifying sites vulnerable to phosphorus loss in agricultural runoff. J. Environ. Qual., 24, 947-951.
Wade, A.J., Hornberger, G.M., Whitehead, P.G., Jarvie, H.P. and Flynn, N., 2001. On modelling the mechanisms that control instream phosphorus, macrophyte and epiphyte dynamics: An assessment of a new model using general sensitivity analysis. Water Resour. Res., 37, 2777-2792.

Wade, A.J., Whitehead, P.G. and Butterfield, D., 2002a. The Integrated Catchments model of Phosphorus dynamics (INCAP), a new approach for multiple source assessment in heterogeneous river systems: model structure and equations. Hydrol. Earth Syst. Sci., 6, 583-606.

Wade, A.J., Durand, P., Beaujouan, V., Wessel, W.W., Raat, K.J., Whitehead, P.G., Butterfield, D., Rankinen, K. and Lepisto, A., 2002b. A nitrogen model for European catchments: INCA, new model structure and equations. Hydrol. Earth Syst. Sci., 6, 559582.

Wade, A.J., Whitehead, P.G., Hornberger, G.M. and Snook, D.L., $2002 \mathrm{c}$. On modelling the flow controls on macrophyte and epiphyte dynamics in a lowland permeable catchment: the River Kennet, southern England. Sci. Total Envir., 282/283, 375-393.

Wade, A.J., Whitehead, P.G., Hornberger, G.M., Jarvie, H.P. and Flynn, N., 2002d. On modelling the impacts of phosphorus stripping at sewage works on in-stream phosphorus and macrophyte/epiphyte dynamics: a case study for the River Kennet. Sci. Total Envir., 282/283, 395-415.

Wade, A.J., Butterfield, D., Raat, K.J. and Whitehead, P.G., 2004. Effectiveness of eutrophication control by phosphorus reduction: development of the INCA-P model. R \& D Final Report P2137, Science Report SC980009/SR, Environment Agency, Bristol, UK. 151pp. 